Pecvnia, 4 (2007), pp. 143-154

\title{
De cómo rendir cuentas a Dios y a los hombres: Las invocaciones sacras en los libros de cuentas del renacimiento inglés ${ }^{*}$
}

Las invocaciones sacras en los libros de cuentas son una costumbre que comienza en la época medieval y que se extiende hasta el siglo XVIII. En ellas se concentra la fe medieval, la confianza en uno mismo del renacimiento y la combinación de lo pagano con lo cristiano.

Esta costumbre iniciada en Italia, se propagó por toda Europa con la publicación del tratado de Fra Luca Pacioli. Se diseminó la partida doble, pero también todas las costumbres que en su entorno eran habituales entre los mercaderes.

\author{
J. Lanero Fernández \\ juan.lanero@unileon.es \\ E. Ortega Montes \\ Universidad de León
}

Fac. de Ciencias Económicas y Empresariales

Campus de Vegazana s/n

24071 León (España)

Pious inscriptions in account books were already customary in the medieval ages and lasted until 18th century. They were an expression of the medieval faith, the renaissance self-reliance together with a combination of pagan and Christian beliefs.

This tradition started in Italy and expanded all over Europe with the publication of Fra Luca Pacioli's treatise in 1494. The doubleentry system was spread out and with it the habits which were usual among merchants. 
El presente estudio pretende hacer una revisión del uso de estas invocaciones sacras desde las recomendaciones que Pacioli realiza hasta las que aparecen en algunos tratados comerciales del siglo XVIII.

Fra Luca Pacioli condensó en su tratado lo que los mercaderes italianos venían practicando desde mucho antes de 1494. El fraile italiano sistematizó en la Summa los principios de la teneduría de libros por partida doble, pero no se olvidó de otras costumbres: las invocaciones sacras.

Palabras clave: Invocación sacra, partida doble, sentimiento religioso
The focus of the present study is a revision of these pious inscriptions starting with the suggestions made by Pacioli and up to the ones that appear in some commercial treatises of the $18^{\text {th }}$ century.

Fra Luca Pacioli gathered in his treatise what the Italian merchants had practised for a long time before 1494. The Italian monk systematized the principles of double-entry bookkeeping in his Summa and he did not forget to include some other practises such as pious inscriptions whenever an account was opened.

Key words: Pious invocations, double-entry, religious feeling

En la primera obra impresa que trata de la teneduría de libros, su autor, Fra Luca Pacioli, instruye a los mercaderes para que el nombre de Dios aparezca al comienzo de todo documento. Igualmente, aconseja que todo buen católico estampe el signo de la cruz en el primero de una serie correlativa de Libros Diarios o Mayores que guarden relación con su negocio. Con esta forma de proceder -asegura-, se ahuyenta a nuestros enemigos espirituales y tiembla el maligno. Los Diarios posteriores se marcan con las letras del Abecedario ${ }^{1}$.

Con esta recomendación, Fra Luca Pacioli no se limitaba a expresar sus propias creencias religiosas; también expresaba la práctica habitual de su Italia contemporánea. Era costumbre que los contratos mercantiles se iniciaran con expresiones tales como "En el nombre de Dios". Se conservan ejemplos de los contratos internacionales de los Medici de Florencia que, con frecuencia, empiezan con las palabras "Col nome di Dio e di Buenaventura"; esto es: en el nombre de Dios y de la buena suerte. Se trata de una combinación de invocaciones que se ha venido en considerar como ejemplo de la reconciliación, en los primeros tiempos del renacimiento, de la fe medieval con la confianza en uno

Para una traducción española de la Summa de Arithmética de Fra Luca Pacioli (1494), véase De las cuentas y las escrituras, Estudio introductorio, traducción y notas por Esteban Hernández Esteve, Madrid: Asociación Española de Contabilidad y Administración de Empresas, 1994. 
mismo renacentista y como expresión de la coexistencia de lo cristiano y lo pagano ${ }^{2}$.

Los libros de cuentas italianos del siglo XVI, y aun de etapas anteriores, comienzan, de forma invariable, con una invocación del nombre de Dios. Las invocaciones más detalladas incluyen a la Virgen María y a ciertos santos, o a todos los santos, de forma colectiva, implorando la concesión de buena salud, larga vida y beneficios. Muchas son las muestras que podrían traerse a colación; bástenos con las tres que siguen ${ }^{3}$.

Un ejemplo elaborado es el del libro vermiglio (1332-37) de la compañía florentina de Jacopo Girolami, Filippo Corbizzi y Tommaso Corbizzi. El primer párrafo de la larga invocación dice así:

Al nome di Dio e de la beata Vergine Madre Madonna Santa Maria e di messer Santo Giovanni Batista Evangelista e di tutti Santi e Sante di Paradiso, che per loro santa pietà e miserichordia ne chonciedano grazia di santa e di lungha e buona vita, chon acrescimeto di buone persone e di guadagnio, cho salvameto delle nostre anime e di chorpo ${ }^{4}$.

La invocación prosigue con más detalles de la compañía. El adjetivo vermiglio se refiere al color de la encuadernación original y tenía como misión diferenciar este libro de cuentas de los demás. La letra "C" que aparece en una hoja de pergamino, con la que comienza el libro, demuestra que éste es el tercero de una serie, o el cuarto, siempre y cuando el primero estuviera marcado con el signo de la cruz.

Una invocación mucho más sencilla es la que aparece al comienzo del Libro Mayor del mercader veneciano Giacomo Badoer, que se empezó en 1436:

Al nome de Dio de bon guadagno, libro de mi Jachomo Badoer del viazo da Costantinopoli, nel qual luogo zunsi a

2 Véase A. Warburg, Gesammelte Schriften, Leipzig: B.G. Teubner, 1932, vol. I, p. 151. Para ver documentos italianos similares, cfr. Robert S. Lopez and Irving W. Raymond, Medieval Trade in the Mediterranean World. Illustrative Documents Translated with Introductions and Notes, With a foreword and bibliography by Olivia Remie Constable, New York: Columbia University Press, 2001.

3 Cfr. A. Sapori, Mercatores, con prefazione di Giorgio Molfino, Milano: Garzanti, 1941, p. 104; T. Antoni, Il Libro dei Bilanci di una Azienda Mercantile del Trecento, Pisa, 1967.

Sígnale del C..., Torino, 1963.

4 Cfr. M. Chiaudano, ed., Il Libro Vermiglio di Corte di Rome e di Avignone del 
di 2 setenbre 1436 a mezo zorno chon legalie chapetanio miser Piero Chontarini ${ }^{5}$.

El tercer ejemplo de invocación pertenece a un libro de cuentas (libro di ricordanze) del escultor florentino Lorenzo Ghiberti (1378-1455), referente a los gastos realizados en la propiedad que poseía a unos diez kilómetros de Florencia:

Mccccxxxxi a di xxvi daprile. Al nome di dio e della sua madre madonna Sancta Maria e di tutta la corte del paradiso e del beato messer sancto Piero e del beato messer sancto Pagliolo e del beato messer sancto Giovanni Batista e del beato Giovanni vagielista e di tutti li sancti e sante di paradiso.... Al nome di dio e chiamasi Libro di ricordanze segnato $A^{6}$.

II

Según el historiador económico italiano Armando Sapori, la tradición de las invocaciones religiosas se conservó en Italia hasta el siglo XVIII, aunque, poco a poco, se convirtió más en una cuestión de repetición mecánica que en una expresión o reflejo de un profundo sentimiento religioso, como sucedió en la época medieval. Sapori explica la omnipresencia de este sentimiento religioso en los asuntos comerciales con el hecho de que algunas compañías del siglo XIV abrían las cuentas en sus Libros Mayores por y en nombre de Dios: cuentas per Dio o per messere Domeneddio. En estas cuentas se abonaba una parte de los beneficios cuando se cerraba el Libro Mayor y se cargaba como donaciones para beneficencia':

Voilà qui est caractéristique et fondamental: les compagnies, à chaque constitution et reconstitution successive du budget, créaient un "fonds pour les pauvres" dans le capital de la société. Sur les livres de comptabilité, ce fonds était mis au nom de "Messer le Bon Dieu", qui représentait les pauvres nantis, de cette façon,

\footnotetext{
5 Umberto Dorini e Tommaso Bertelè, /l Libro dei Conti di Giacomo Badoer (Costantinopoli 1436-1440), Istituto Poligrafico dello Stato, 1956, p. 1.

6 Citado en Harold Edey and B.S. Yamey, eds., Debits, Credits, Finance and Profits, London: Sweet \& Maxwell, 1974, p. 144.

A. Sapori, Mercatores, ed. cit., pp. 106-7; Armando Sapori, Le Marchand Italien au Moyen Age, Introduction de Lucien Febvre, Paris: Librarie Armand Colin, 1952.
} 
du titre d'associés. Lors de la répartition du dividende, une part des bénéfices proportionnelle à ce capital revenait donc aux malheureux. Une faillite survenait-elle? Les pauvres, qui avaient été jusqu'alors associés de la compagnie, se transformaient de sociétaires en créanciers; les sommes qui leur revenaient après liquidation étaient remises à l'archevêche ou à des associations d'oeuvre de bienfaisance et, dans ce cas, payées non en sommes d'argent, mais sur les biens-fonds agricoles appartenant aux associés, avec droit de préférence.

Además, podemos añadir que las invocaciones sacras, que conferían cierta seriedad al contenido de los libros de cuentas, también sirvieron para incrementar el valor de estos libros como prueba ante los tribunales de justicia. Algunas dedicatorias, recogidas en las primeras páginas, contenían detalles específicos que pudieron ser útiles para que una tercera parte fuera capaz de interpretar el contenido de las cuentas o de determinar su fiabilidad. Nos referimos a detalles como el número de páginas, amplitud de los registros, disposición de las partidas y los nombres de aquellos que las anotaban. Por ejemplo: la inscripción en el Libro Mayor de la compañía bancaria de Filippo Borromei, que se llevó en Londres de 1436 a 1439, explica que el contenido incluirá deudores, acreedores, las mercaderías que se compraran o vendieran y los gastos pertinentes.

La primera página de un libro de cuentas de Americo Benci, correspondiente al año 1459, informa al lector que se denomina "libro secreto, marcado con una $A$, de 100 páginas", y que se llevará al modo de Venecia, es decir, en una página los cargos y en la otra los abonos, comenzando en el nombre de Dios y de la buena suerte ${ }^{8}$.

III

El uso de las invocaciones sacras al comienzo de los libros de cuentas se extendió desde Italia al resto de Europa junto a la práctica de encabezar páginas y cuentas con las palabras Laus Deo. La utilización de semejantes invocaciones se recomienda en los primeros tratados contables ingleses. Así, la primera página del ejemplo de Libro Mayor que James Peele recoge en The maner and fourme, de 1553, reza así:

8 F. Besta, La Ragioneria, Milan, vol. III, pp. 326, 328-9. 


\section{Anno M.D.LIII \\ Maie the. Xxiiij. daie

$$
+
$$

The Quaterne or

greate booke of accomptes, belongyng to

me Fraunces Bonde of London

Grocer, dwellyng in the $\mathrm{Pa}$ -

rishe of sainct Olifes in

Marke Lane.

The name of God be our helpe.

F.B. ${ }^{9}$

John Weddington, al escribir su tratado de 1567, entre las "Rules verry necessarie to be obseruid by all marchantis, In the kepinge of ther accomptis or reconningis \& c." dice en primer lugar:

Fyrst it is verri nedefull for all marchantis to haue vnderstandinge and knowlidge in all manner of marchādize, and to write and rede perfectli, and also promptli to cast ther accomptis, by Arismeticke or countres, and at the beginninge of their writingis to put fyrst the name of God, makinge the signe of the crosse the wiche is most commonli vsid amongest all Christen men ${ }^{10}$.

La puesta en práctica de estas recomendaciones se observa con claridad en la invocación del Libro Diario (1546-52) de Sir Thomas Gresham. Según las indicaciones que ya hemos visto, está marcado con el signo de la cruz, lo que implica que es el primero de su serie (Figura 1):

$$
\text { + LAUS. DEO. } 1546
$$

26. Apryll.

In the name of God Amen.

This present boke shalbe the

Jornall called + apperteyning to me Thomas Gresham

of London mercer for therin to wryte with my owne hande

or els with the hand of my prentys Thomas Bradshawe

alle my hoole trayne and doynges and out of the

saide Jornall, to wryte it into the greate

booke called the leger which shalbe

\footnotetext{
James Peele, The maner and fourme how to kepe a perfecte reconyng, after the order of the moste worthie and notable accompte, of Debitour and Creditour..., 1553. Imprinted at London, by Richard Grafton, printer to the kinges Maiestie. Cum priuilegio ad imprimendum solum.

10 John Weddington, A breffe Instruction, and manner howe to kepe marchantes bokes, of accomptes. After the order of Debitor and Creditor, as vvell for proper accomptes, partable, factory, and other \& c. Verry nedefull to be knovven, and vsid of all men, in the feattis of marchandize... M.D.LXVII. Prenttyd ind Andvvarpe, by Petter van Keerberghen.
} 


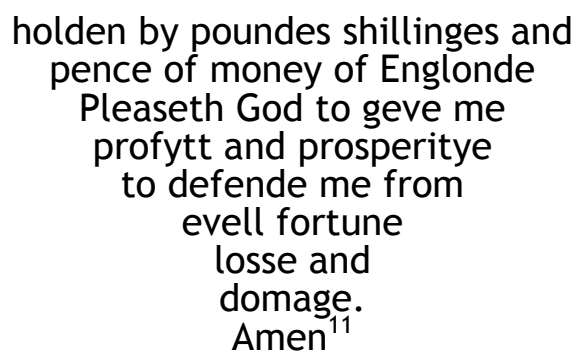

Debajo de la invocación aparece la marca de mercader de Gresham. Por la disposición gráfica, las palabras y frases empleadas, así como su orden, parece que Gresham utilizó como modelo la invocación del modelo de Diario de la Nieuwe Instructie de Ympyn, publicada en Amberes en 1543. Amberes era una ciudad que Gresham conocía muy bien. Como sabemos, la edición flamenca de Ympyn se tradujo al inglés en 1547. Por infortunio, al único ejemplar que se conserva le arrancaron el modelo de libros de cuentas. En todo caso, difícilmente pudo consultar Gresham la versión inglesa de 1547, pues su Libro Diario comienza en Abril del año anterior:

+ Laus Deo. M.D. xxxvj. / 28. Decembre.

In den name des Heeren

Sal dir boeck wesen eenen Journael / dat is da-

ghelijcx boeck / gheteekent oft ghenaempt + /

Toebehoorende my Niclaes Forestain / omine

daer inne te scriuene van mijnder hant alle my-

ne hanteringhe ende affairen / die ick van desen daghe afte

doene sal hebben / ende van hier voorts te draghen op

den grooten boeck / Ende sal ghehouden wesen in

ponden/schellinghen / ende penningen vlaem-

scher munten. God wille my verleenen

ghewin ende voerspoet / ende

behoeden van onghe-

luck ende van

verliese.

AMEN. ${ }^{12}$

11 Cfr. Peter Ramsey, "Some Tudor Merchants' Accounts", en A.C. Littleton and B.S. Yamey, eds., Studies in the History of Accounting, London: Sweet \& Maxwell Limited, 1956, p. 189.

12 Jan Ympyn Christoffels, Nieuwe instructie ende bewijs der looffelijcker consten des Rekenboecks ende Rekeninghe te houdene nae die Italiaensche maniere... Ghetranslateert met grooter diligentien / wt die Italiaensche tale in onser spraken duer Jan Ympyn Christoffels (saligher memorien)..., Coopman van Antwerpen, 1543. 
Figura 1. Portada (segunda página) del Diario de Gresham

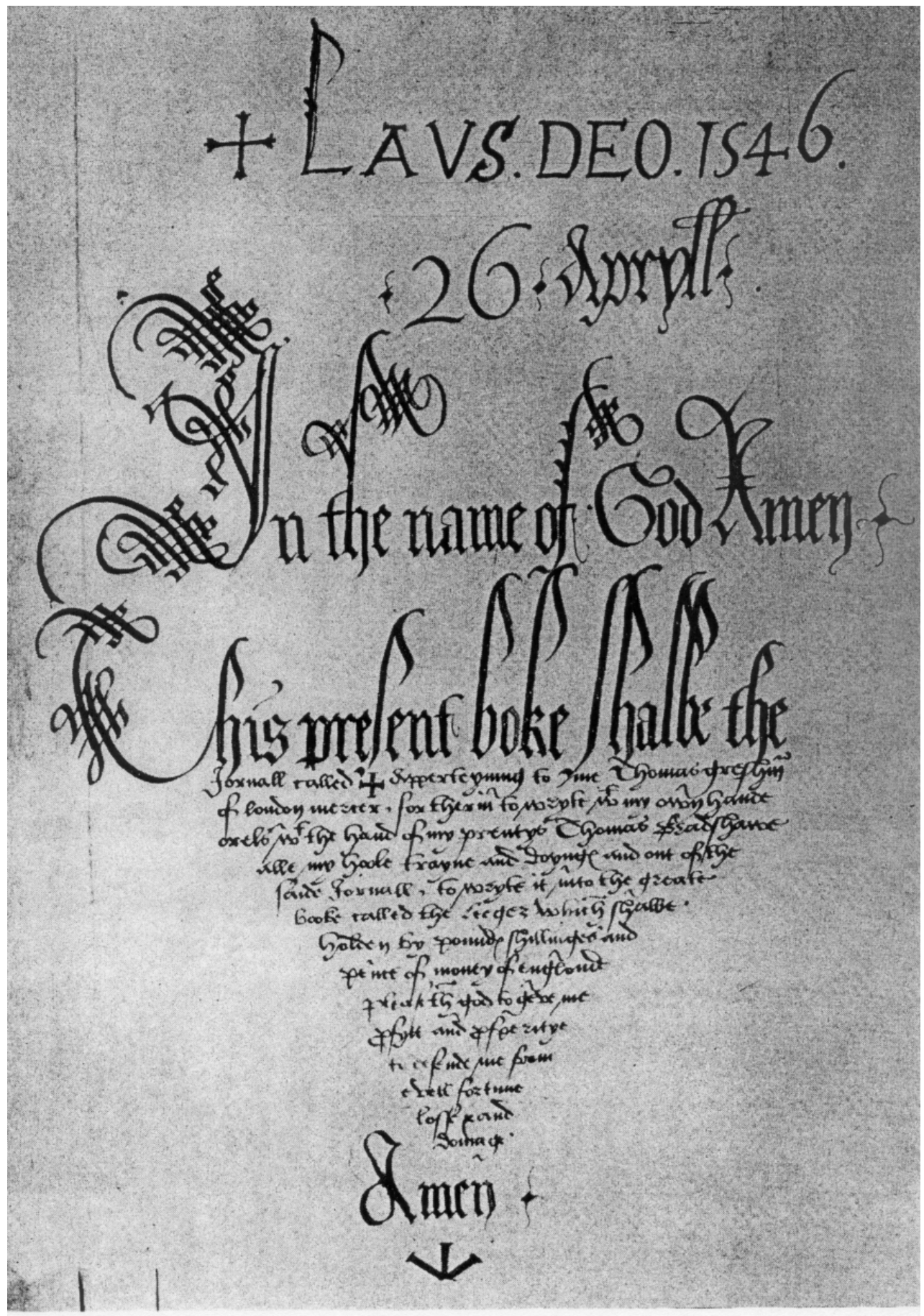


Otro ejemplo inglés es el que tenemos en el "Leager or greate Booke of accomptes of Letter A" perteneciente a William Hoskins, que comienza en 1655. Las palabras "In the name of God Amen" figuran en la cabecera de la primera página ${ }^{13}$.

IV

Todo parece indicar que el uso de las invocaciones sacras empezó a decaer mucho antes en Inglaterra que en Italia, aunque algunos términos como Laus Deo se siguieron utilizando hasta bien entrado el siglo XVIII.

Roger North explica por qué una persona tiene que comenzar sus cuentas con un inventario y proceder según él indica. Lo hace en The Gentleman Accomptant, de 1714:

... to begin a regular Accompt, there must be a Fund, or Capital Stock, out of which all the Accompts, that may possibly grow, waste, increase, or continue in Par must flow. And to begin a set of Books with the first Thing that stirs, and so go on, as Things move, is an heedless Undertaking, and will not go on well, nor close tolerably; for wither is the Profit, or Loss to go? For this Reason the Merchants (having a form of Godliness write first Laus Deo, and then an Inventory of all their wordly Estate, under such Heads, as they judge, will make proper Accompt in their Books; and then the Accompt of Stock, or Estate, as they are pleased to intitle it, after the foresaid Consecration, and a Declaration, that it is their Inventory, begins thus, viz... ${ }^{14}$.

Incluso cuando las invocaciones sacras cayeron en desuso, palabras que vienen a decir "Alabado sea Dios", pueden encontrarse en partidas de beneficios en los libros de cuentas ingleses que se conservan

13 William Hoskins, Ledger A, Goldsmiths' Library, University of London, MS. 265.

14 [Roger North], The Gentleman Accomptant: or, an Essay to unfold the Mystery of Accompts. By Way of Debtor and Creditor, Commonly called Merchants Accompts..., Done by a Person of Honour..., London: Printed for E. Curil..., 1714, pp. 23-4. La atribución de esta obra a Roger North se debe a David Murray en su obra Chapters in the History of Book-keeping, Accountancy and Commercial Arithmetic, Glasgow: Jackson, Wylie \& Co., 1930, p. 262. R.B. Grassby, del Jesus College de Oxford, sostiene la idea -que fundamenta en sus estudios realizados de los manuscritos de la North Library (Biblioteca Británica)-, de que algunas partes de The Gentleman Accomptant tienen su origen en un material no publicado del que sería autor Sir Dudley North, que habría instruido a su hermano Roger en contabilidad. 
del siglo XVII. Así, la cuenta anual de 1648 de Thomas Cullum, termina con la frase "I humbly thank my God"15.

Del mismo modo, las páginas sucesivas del libro de cuentas de Robert Loder, en las que están anotadas las partidas de beneficios tienen alguna invocación sacra. Corría la década de 1610-1620:

- The Lorde my God his aboundant mercies be magnified and exalted therfore. Amen. [1616. Fol. 47v]

- The Lorde be praysed for it. Amen [1616. Fol. 48r]

- Soe that the whole sume of cleare proffites given unto me most unworthy therof by nature, by my most mercifull God \& Father in Christ Jesus my saviour is CCxxiijl. xs. vijd. [1616. Fol. 49r]

- This was nothing like ye yeld in the last yeare before, the Lorde blesseth as pleaseth him, his mercies be magnified for these \& all other his blessings, for they are more then we doe deserve. Amen [1617. Fol. 51r] $]^{16}$

La expresión de este sentimiento es una reminiscencia de las palabras que se encuentran al final del modelo de Diario en el tratado de Ympyn. Inmediatamente después de que el beneficio obtenido durante el período señalado se transfiera a la cuenta de capital: "Alabanza y honor a Dios Todopoderoso que me lo ha dado. Amen". Las palabras de la versión francesa de Ympyn son: "Louenge, \& honneur a Dieu le tout puissant que ce ma donne. Amen".

Resulta interesante, en términos historiográficos, comparar estas expresiones con los encabezamientos del Debe y el Haber, respectivamente, de la cuenta de pérdidas y ganancias del Libro Mayor de Francesco Datini de Prato en la temprana fecha de 1383: Aquí se anotarán, Dios lo impida, las pérdidas sufridas en mercaderías; y los beneficios de las mercaderías se anotarán aquí, Dios nos dé salud y beneficios, Amen $^{17}$.

15 Cfr. B.S. Yamey, "Some Topics in the History of Financial Accounting in England 1500-1900" en W.T. Baxter and Sidney Davidson eds., Studies in Accounting Theory, London: Sweet \& Maxwell Limited, 1962, pp. 14-43; p. 23.

16 G.E. Fussell, ed., Loder's Farm Accounts 1610-1620, Camden Third Series, vol. LIII, London: The Royal Historical Society, pp. 118, 119, 122, 125.

17 E. Peragallo, Origin and Evolution of Double Entry Bookkeeping. A Study of Italian Practice from the Forteenth Century, New York: American Institute Publishing Co., 1938, p. 26. Véase también Iris Origo, The Merchant of Prato, London: The Folio Society, 1984. 
Con independencia de que los mercaderes ingleses emplearan estas expresiones piadosas con menos frecuencia, en los tratados comerciales del siglo XVIII se les insta a que lleven sus libros lo mismo que sus conciencias: siempre limpios, ordenados y al día; de lo contrario, habrán de rendir cuentas a los hombres y a Dios:

... Tradesman's Books, like a Christian's Conscience, should always be kept clean and neat; and he that is not careful of both, will give but a sad Account of himself either to God or Man ${ }^{18}$.

\section{BIBLIOGRAFÍA}

BAXTER, W.T. and Sidney DAVIDSON eds. (1962) Studies in Accounting Theory. London: Sweet \& Maxwell Limited.

CHRISTOFFELS, Jan Ympyn (1543) Nieuwe instructie ende bewijs der looffelijcker consten des Rekenboecks..., Antwerpen: Coopman.

DoRINI, Umberto e Tommaso BerTelè (1956) Il Libro dei Conti di Giacomo Badoer (Costantinopoli 1436-1440), Istituto Poligrafico dello Stato.

EDEY, Harold and B.S. YAMEY eds. (1974) Debits, Credits, Finance and Profits. London: Sweet \& Maxwell.

LOPEZ, Robert S. and Irving W. RAYMOND (2001) Medieval Trade in the Mediterranean World. Illustrative Documents Translated with Introductions and Notes, With a foreword and bibliography by Olivia Remie Constable. New York: Columbia University Press.

MURRAY, David (1930) Chapters in the History of Book-keeping, Accountancy and Commercial Arithmetic. Glasgow: Jackson, Wylie \& Co.

[NORTH, Roger] (1714) The Gentleman Accomptant..., London: E. Curil.

ORIGO, Iris (1984) The Merchant of Prato. London: The Folio Society.

18 Véase "A Compendious System of Merchants Accounts, or the Italian Method of Bookkeeping," en The Universal Library of Trade and Commerce; or a General Magazine for Gentlemen, Ladies, Merchants, Tradesmen, School-Masters, and All Who Are Any Ways Concerned in Business, or the Education of Youth of Either Sex, as Well as for Young Clerks, Apprentices \& C. \& C. ..., By the Most Celebrated Masters..., London: Printed for J. Robinson, 1747, p. 13. 
PACIOLI, Luca (1494) De las cuentas y las escrituras, Estudio introductorio, traducción y notas por Esteban Hernández Esteve, Madrid: Asociación Española de Contabilidad y Administración de Empresas.

PEELE, James (1553) The maner and fourme how to kepe a perfecte reconyng, after the order of the moste worthie and notable accompte, of Debitour and Creditour... London: Richard Grafton.

Peragallo, E. (1938) Origin and Evolution of Double Entry Bookkeeping. A Study of Italian Practice from the Forteenth Century, New York: American Institute Publishing Co.

SAPORI, A. (1941) Mercatores, con prefazione di Giorgio Molfino, Milano: Garzanti.

SAPORI, Armando (1952) Le Marchand Italien au Moyen Age, Introduction de Lucien Febvre, Paris: Librarie Armand Colin.

The Universal Library of Trade and Commerce... (1747) London: J. Robinson.

WARBURG, A. (1932) Gesammelte Schriften, Leipzig: B.G. Teubner.

WEDDINGTON, John (1567) A breffe Instruction, and manner howe to kepe marchantes bokes, of accomptes. After the order of Debitor and Creditor..., Andvvarpe: Petter van Keerberghen.

YAMEY, B.S. (1962) "Some Topics in the History of Financial Accounting in England 1500-1900" en W.T. BAXTER and Sidney DAVIDSON eds., Studies in Accounting Theory. London: Sweet \& Maxwell Limited, pp. 14-43. 